A RCHIWA, BIBLIOTEKI

I MUZEA KOŚCIELNE 109 (2018)

https://doi.org/10.31743/abmk.2018.109.14

AGATA MUC* - KATOWICE

\title{
ELEKTRONICZNA BIBLIOGRAFIA NAUK TEOLOGICZNYCH JAKO ŹRÓDLO DO BADAŃ HISTORYCZNO-TEOLOGICZNYCH
}

\section{Wprowadzenie}

Bibliografie dziedzinowe stanowią niezwykle ważne źródło informacji, ponieważ zazwyczaj rejestrują większą liczbę publikacji aniżeli bibliografie narodowe, w których rzadziej są uwzględniane materiały specjalistyczne lub wydawane w niskich nakładach. Podobnie jak wiele innych bibliografii specjalnych, ze względu na systematyczną aktualizację danych, niskie koszty użytkowania oraz większą swobodę w doborze narzędzi przeszukiwania zasobów coraz częściej tworzone są w postaci elektronicznej ${ }^{1}$.

W Polsce tego rodzaju tendencje zaczęły się pojawiać na początku lat 90 . ubiegłego stulecia, kiedy wraz z rozwojem komputeryzacji w bibliotekach, zaczęła rodzić się myśl o tworzeniu nie tylko komputerowych katalogów bibliotecznych, ale także bibliograficznych baz danych ${ }^{2}$. Pierwsze tego rodzaju bazy z zakresu nauk teologicznych zaczęto tworzyć w Bibliotece Uniwersytetu Kardynała Stefana Wyszyńskiego w Warszawie. Już 1993 r. ks. Stanisław Warzeszak ${ }^{3}$ rozpoczął pracę nad Bibliografia Teologii Moralnej i Etyki, która od początku

* Agata Muc - mgr bibliotekoznawstwa i informacji naukowej; kustosz dyplomowany w Bibliotece Teologicznej Uniwersytetu Śląskiegow Katowicach; e-mail: agata.muc@us.edu.pl

${ }^{1}$ A. Bajor, H. Langer, Polskie spisy i serwisy bibliograficzne dostepne w Internecie, w: Biblioteki szkót wyższych $w$ spoleczeństwie wiedzy: uwarunkowania $i$ wybrane zagadnienia, t. 1, Konteksty i uwarunkowania, red. Z. Gębołyś, Katowice 2010, s. 106. Zob. także J. Sadowska, Główne problemy wspótczesnej polskiej bibliografi, w: Bibliografia: teoria, praktyka, dydaktyka: praca zbiorowa, red. J. Woźniak-Kasperek, M. Ochmański, Warszawa 2009, s. 45.

${ }^{2}$ J. Sadowska, Polskie dziedzinowe bibliograficzne bazy danych w perspektywie lokalnej i globalnej, w: Bibliograficzne bazy danych: kierunki rozwoju i możliwości wspólpracy. Ogólnopolska konferencja naukowa z okazji 10-lecia bazy danych BazTech. Bydgoszcz, 27-29 maja 2009, [Warszawa] 2009, http://www.ebib.pl/publikacje/matkonf/mat19/sadowska.php (dostęp: 01.03.2017).

${ }^{3}$ Ks. prof. dr hab. Stanisław Warzeszak (1958-2017), pracownik Papieskiego Wydziału Teologicznego w Warszawie „Collegium Joanneum”, specjalista z zakresu bioetyki i teologii moralnej. 
funkcjonowała tylko w wersji elektronicznej ${ }^{4}$. Inne bazy powstawały w wyniku przenoszenia danych z bibliografii wydawanych $\mathrm{w}$ wersji drukowanej do postaci cyfrowej. W ten sposób na podstawie Bibliografii Historii Kościoła w Polsce za Lata ... ${ }^{5}$ utworzono Bibliografię Historii Kościoła ${ }^{6}$, a dane zaczerpnięte z Polskiej Bibliografii Nauk Kościelnych za Rok ...7 umieszczono w Polskiej Bibliografii Nauk Kościelnych ${ }^{8}$. Natomiast Polska Bibliografie Antyku Chrześcijańskiego ${ }^{9}$ stworzył ks. Józef Naumowicz ${ }^{10}$ wykorzystując własne opracowania opublikowane wcześniej w czasopiśmie „Vox Patrum”"11.

W pracach nad bazami powstającymi w Bibliotece Uniwersytetu Kardynała Stefana Wyszyńskiego uczestniczył ks. Krzysztof Gonet ${ }^{12}$, propagator komputeryzacji bibliotek w ramach Federacji Bibliotek Kościelnych FIDES [dalej: Federacja FIDES]. Podstawowym celem działalności stowarzyszenia było ujednolice-

${ }^{4}$ D. Szumilas, S. Warzeszak, Baza danych bibliograficznych z zakresu teologii moralnej i etyki (http://www.biblioteka.uksw.edu.pl/), „Warszawskie Studia Teologiczne”, 22 (2009) nr 1, s. 358.

${ }^{5}$ Bibliografia wydawana przez Akademię Teologii Katolickiej w latach 1977-1997. Zob. Bibliografia Historii Kościoła w Polsce za Lata 1944-1970, cz. 1-3, oprac. E.H. Wyczawski, Warszawa 1977; F. Stopniak, Bibliografia Historii Kościoła w Polsce za Lata 1971-1972, Warszawa 1977; M. Banaszak, Bibliografia Historii Kościoła w Polsce za Lata 1973-1974, Warszawa 1978; R. Żmuda, Bibliografia Historii Kościoła w Polsce za Lata 1975-1977, cz. 1-2, Warszawa 1982; M. Banaszak, P. Latawiec, Bibliografia Historii Kościoła w Polsce za Lata 1978-1979, Warszawa 1985; R. Żmuda, P. Latawiec, Bibliografia Historii Kościoła w Polsce za Lata 1980-1981, cz. 1-2, Warszawa 1989; R. Żmuda, Bibliografia Historii Kościoła w Polsce za Lata 1982-1984, cz. 1-2, Warszawa 1997.

${ }^{6}$ Bibliografia Historii Kościoła, http://baza.biblioteka.uksw.edu.pl/makwww/?BM=07 (dostęp: 01.03.2017).

${ }^{7}$ Bibliografia wydawana przez Akademię Teologii Katolickiej w latach 1973-1986. Zob. Polska Bibliografia Nauk Kościelnych za Rok 1971, red. J.R. Bar, R. Sobański, Warszawa 1973; Polska Bibliografia Nauk Kościelnych za Lata 1972-1973, red. R. Sobański, Warszawa 1979; Polska Bibliografia Nauk Kościelnych za Lata 1974-1976, cz. 1-2, red. W. Rosłon, J. Laskowski, Warszawa 1983; Polska Bibliografia Nauk Kościelnych za Lata 1977-1979, z. 1-2, red. L. Balter, Warszawa 1986.

${ }^{8}$ Polska Bibliografia Nauk Kościelnych, http://baza.biblioteka.uksw.edu.pl/makwww/?BM=06 (dostęp: 01.03.2017).

${ }_{9}$ Polska Bibliografia Antyku Chrześcijańskiego, http://bazy.biblioteka.uksw.edu.pl/bac.php (dostęp: 01.03.2017).

${ }^{10}$ Ks. prof. dr hab. Józef Naumowicz (1956-), pracownik Uniwersytetu Kardynała Stefana Wyszyńskiego w Warszawie, specjalista z zakresu chrześcijaństwa antycznego i patrologii.

${ }^{11}$ D. Szumilas, Dziedzinowe bazy bibliograficzne Biblioteki Uniwersytetu Kardynała Stefana Wyszyńskiego w Warszawie, w: Bibliograficzne bazy danych: kierunki rozwoju i możliwości wspótpracy. Ogólnopolska konferencja naukowa z okazji 10-lecia bazy danych BazTech. Bydgoszcz, 2729 maja 2009, red. L. Derfert-Wolf, L. Szczepańska, [Warszawa] 2009, http://www.ebib.pl/publikacje/matkonf/mat19/szumilas.php (dostęp: 01.03.2017).

${ }^{12}$ Ks. Krzysztof Gonet (1957-), bibliotekarz i twórca Federacji Bibliotek Kościelnych FIDES, dyrektor Biura ds. Rozwoju i Komputeryzacji Federacji FIDES, w roku 2004 otrzymał tytuł „Honorowego Członka Federacji Bibliotek Kościelnych FIDES”: K. Gonet, Autobiografia bibliotekarza i bibliotekoznawcy. (Do października roku 2016), „Fides: Biuletyn Bibliotek Kościelnych”, 1(44) (2017) s. 181-190; zob. także Ks. Krzysztof Gonet. [biogram], w: Kronika X-lecia Papieskiego Wydziatu Teologicznego w Warszawie, „Warszawskie Studia Teologiczne”, 13 (2000) s. 240-242. 
nie prac nad komputeryzacją bibliotek kościelnych przez zbudowanie jednolitego systemu komputerowego i wspólnej bazy katalogowej. Obok prac związanych z ułatwieniem dostępu do informacji katalogowej, na szeroką skalę podejmowano także działania dotyczące tworzenia baz bibliograficznych ${ }^{13}$.

W kolejnych latach za pośrednictwem strony domowej Federacji FIDES zaczęto udostępniać liczne bibliografie odnoszące się do nauk kościelnych, tworzone przez różne osoby oraz instytucje. Obok bibliografii osobowych (np. Jana Pawła II, kard. Stefana Wyszyńskiego) oraz prezentujących zawartość poszczególnych tytułów czasopism (np. „Współczesna Ambona”, „Kielecki Przegląd Diecezjalny"), udostępniano także bazy z opisami publikacji z zakresu określonych specjalności teologicznych (np. Polska Bibliografia Pneumatologiczna 1946-200414).

Ze względu na wciąż rosnącą liczbę baz o różnym poziomie przygotowania i prezentacji danych, zaistniała potrzeba skoordynowania prac oraz stworzenia jednej bibliografii. Pod koniec lat 90. XX wieku uruchomiono Bibliografie Nauk Kościelnych w celu sprawniejszego przeszukiwania kilkunastu rozproszonych baz bibliograficznych. Ostatnia jej wersja z 2005 r. liczyła 37.709 opisów i stanowiła połączenie 17 baz bibliograficznych o różnym zakresie i zasięgu ${ }^{15}$. Pomimo wielu starań oraz dużego nakładu pracy w scalenie wszystkich spisów, efekty nie były wystarczająco zadawalające i budziły wiele zastrzeżeń. Ks. K. Gonet podkreślał wówczas, że: „wszystkie bazy są dopiero na etapie tworzenia. W związku z powyższym nie jest możliwe ścisłe określenie zakresu i zasięgu tej bibliografii. Bibliografia ta nie pretenduje również w żadnym wypadku do kompletności"16.

Potrzeba uregulowania wszystkich prac bibliograficznych okazała się być na tyle ważna, że podczas Kongresu Teologów Polskich w 2004 r. w Lublinie, Zarząd Federacji FIDES zwrócił się z prośbą do uczestników: „o zorganizowanie kontynuacji prac nad polską bibliografią nauk teologicznych i kościelnych (bieżącą i retrospektywną), które zostały zatrzymane na roku 1979 "17. Jednak apel nie spowodował żadnego odzewu ze strony środowiska naukowego ${ }^{18}$.

${ }^{13}$ J.A. Dziewiątkowski, Automatyzacja procesów biblioteczno-informacyjnych $w$ świetle działalności Federacji Bibliotek Kościelnych „Fides”, „Fides: Biuletyn Bibliotek Kościelnych”, 1 (1998) s. 44.

${ }^{14}$ Polska Bibliografia Pneumatologiczna, http://www.fides.org.pl/cgi-bin/makwww/makwww. exe?BM=08 (dostęp: 01.03.2017).

${ }^{15} \mathrm{~J}$. Witczak, 25 lat komputeryzacji bibliotek kościelnych w Polsce - dorobek Federacji FIDES, „Archiwa Biblioteki i Muzea Kościelne”, 106 (2016) s. 337.

${ }^{16}$ Cyt. za J. Witczak, Elektroniczna Bibliografia Nauk Teologicznych Federacji FIDES, Wrocław 3.09.2013 [prezentacja].

${ }^{17}$ K. Gonet, J. Witczak, Apel Federacji Bibliotek Kościelnych FIDES do uczestników Kongresu Teologów Polskich Lublin, 12-15 września 2004 r., „Fides: Biuletyn Bibliotek Kościelnych”, 1-2(20-21) (2005) s. 189; zob. także K. Gonet, To już 17 lat! Przeszłość i plany na przyszłość Federacji Bibliotek Kościelnych FIDES, „Archiwa, Biblioteki i Muzea Kościelne”, 91 (2009) s. 15-23.

${ }^{18}$ J. Witczak, Apel FIDES do polskich teologów i co dalej?, „Fides: Biuletyn Bibliotek Kościelnych", 1-2(20-21) (2005) s. 194. 


\section{Powstanie i rozwój bazy $E B N T$}

Konkretne działania nad stworzeniem jednolitej bieżącej bibliografii nauk teologicznych $\mathrm{w}$ miejsce wielu rozproszonych bibliografii cząstkowych podjęto dopiero w 2010 r. Wówczas zarząd Federacji FIDES i Biblioteka Narodowa podpisały list intencyjny w sprawie współpracy przy tworzeniu Elektronicznej Bibliografii Nauk Teologicznych (dalej: EBNT). Dyrektor Biblioteki Narodowej dr Tomasz Makowski zobowiązał się do bezpłatnego przekazywania danych pochodzących z Zakładu Zawartości Czasopism, na potrzeby tworzenia $E B N T$, przy czym Federacja FIDES ze swojej strony miała - także nieodpłatnie - udostępniać opisy z własnego serwera. Pierwsza wersja bazy powstała ze scalenia rekordów pochodzących z Bibliografii Zawartości Czasopism 1996-2004 i Bibliografii Zawartości Czasopism 2005- (po konwersji z MARC BN do formatu MARC 21) oraz baz bibliograficznych tworzonych przez biblioteki należące do Federacji FIDES. Książnice kościelne przekazały opisy artykułów pochodzących z Opolskiej Bibliografii Teologicznej i Wroctawskiej Bibliografii Teologicznej oraz serii Homo Meditans i Kolekcja Communio.

Oficjalne uruchomienie EBNT nastąpiło 2 kwietnia 2011 r., w szóstą rocznicę śmierci Ojca Świętego Jana Pawła II. W chwili otwarcia, baza liczyła prawie 63.000 rekordów, z czego 6.300 (10\%) utworzyła Federacja FIDES. Opisy sporządzono na podstawie tekstów opublikowanych w 161 tytułach czasopism oraz 243 pracach zbiorowych ${ }^{19}$. Po pięciu latach liczba udostępnianych pozycji bibliograficznych wzrosła do 101.135 , z czego 90.842 opisów artykułów zaczerpnięto z 202 tytułów czasopism, natomiast pozostałe dane pochodziły z 514 prac zbiorowych. Poniższy wykres obrazuje rozwój bazy od momentu uruchomienia do dnia 8 października $2016 \mathrm{r}$.

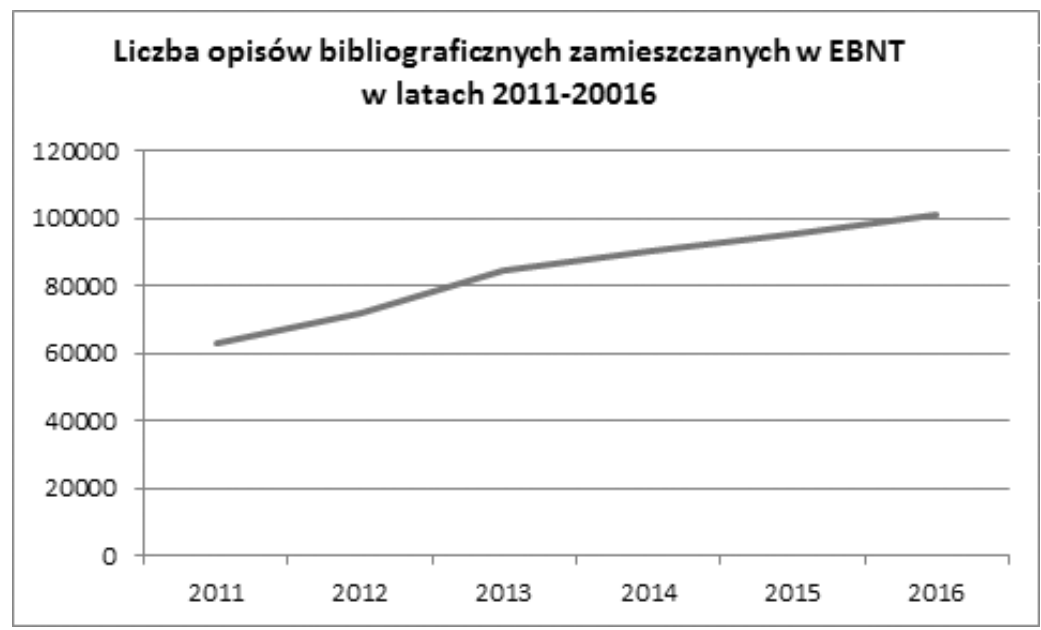

Źródło: opracowanie na podstawie danych z: Elektroniczna Baza Nauk Teologicznych http://www. fides.org.pl/index.php/bazy-on-line/bazy-centralne/59-elektroniczna-bibliografia-nauk-teologicznych (dostęp: 01.03.2017).

${ }^{19} \mathrm{~J}$. Witczak, Funkcjonowanie centralnego serwisu informacji katalogowej i bibliograficznej FIDES w 2011 roku, „Fides: Biuletyn Bibliotek Kościelnych”, 1(34) (2012) s. 173-177. 
Według założeń planu, biblioteki kościelne mają stopniowo uzupełniać braki bibliografii zawartości czasopism wstecz do roku 1980 włącznie, jak również sukcesywnie dostarczać dane bibliograficzne z kolejnych prac zbiorowych. Warto zwrócić uwagę na fakt, że dzięki dofinansowaniu pochodzącemu z Ministerstwa Nauki i Szkolnictwa Wyższego możliwe było wykonanie 1.200 brakujących opisów artykułów z periodyków pochodzących sprzed 1980 r., a nieindeksowanych przez Bibliotekę Narodową. Obecnie zawartość bazy jest uzupełniana w odstępach miesięcznych, o rekordy przekazywane przez Zakład Bibliografii Zawartości Czasopism oraz w sposób nieregularny opisami powstającymi w bibliotekach należących do Federacji FIDES. Poniżej pokazano udział procentowy danych pochodzących z obu instytucji (zob. Wykres 2).

\section{Liczba opisów sporządzonych przez Bibliotekę Narodową i biblioteki Federacji FIDES (stan na 8. 10. 2016 r.)}

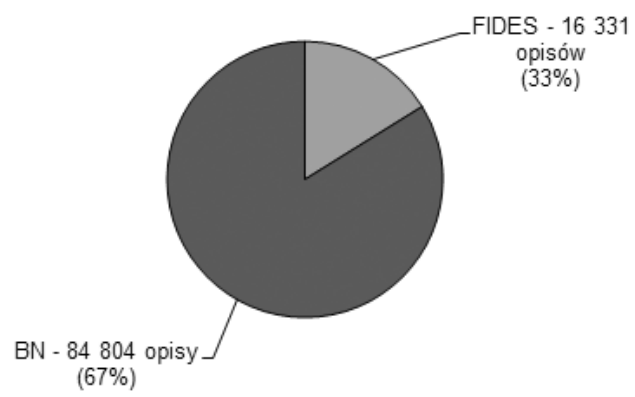

Źródło: opracowanie na podstawie danych z: Elektroniczna Baza Nauk Teologicznych http://www. fides.org.pl/index.php/bazy-on-line/bazy-centralne/59-elektroniczna-bibliografia-nauk-teologicznych (dostęp: 01.03.2017).

Dotychczas do prac nad $E B N T$ włączyły się następujące instytucje:

- Biblioteka Papieskiego Wydziału Teologicznego i Metropolitalnego Wyższego Seminarium Duchownego we Wrocławiu

- Biblioteka Wydziału Teologicznego Uniwersytetu Opolskiego

- Biblioteka Archidiecezjalnego Wyższego Seminarium Duchownego w Białymstoku

- Biblioteka Teologiczna Uniwersytetu Śląskiego w Katowicach

- Biblioteka Zgromadzenia Księży Misjonarzy w Krakowie

- Biblioteka Bobolanum w Warszawie. 
Wiodącą rolę w projekcie pełni Biblioteka Papieskiego Wydziału Teologicznego we Wrocławiu oraz kierujący nią ks. Jerzy Witczak ${ }^{20}$, który jest głównym koordynatorem wszystkich prac związanych nie tylko z samą bibliografią, ale także funkcjonowaniem serwisu informacji katalogowej i bibliograficznej Federacji ${ }^{21}$. Pod jego kierunkiem otrzymane opisy, pochodzące z różnych baz oraz lat, zostały ujednolicone, poprawiono indeks haseł przedmiotowych, jak też udało się skontrolować kompletność wszystkich danych w ramach poszczególnych tytułów. Ponadto uzupełniono część opisów z Biblioteki Narodowej o streszczenia, tytuły obcojęzyczne, spisy treści i linki do wersji pełnotekstowych w polskich bibliotekach cyfrowych.

\section{Wkład Biblioteki Teologicznej Uniwersytetu Śląskiego w EBNT}

Na uwagę zasługują również działania podejmowane przez Bibliotekę Teologiczną Uniwersytetu Sląskiego w Katowicach, która od momentu uruchomienia $E B N T$ aktywnie włączyła się w prace nad tworzeniem i uzupełnianiem bazy. Jeszcze przed przystąpieniem do wprowadzania danych, jeden z bibliotekarzy został skierowany na szkolenia prowadzone przez Bibliotekę Narodową, co znacznie usprawniło późniejszą pracę nad bibliografią. Szkolenia obejmowały problematykę związaną z opracowaniem przedmiotowym oraz stosowaniem języka haseł przedmiotowych Biblioteki Narodowej. Ponadto, ze względu na potrzebę korzystania z Centralnej Kartoteki Haseł Wzorcowych NUKAT, równie przydatne okazały się warsztaty prowadzone on-line przez centrum NUKAT. Warto podkreślić, że dobry poziom przygotowania rekordów prezentowanych w EBNT jest także efektem stałych konsultacji odbywających się w ramach Federacji FIDES podczas całego procesu opracowywania artykułów.

W momencie przystapienia do projektu, Biblioteka Teologiczna zadeklarowała, że jej udział w bibliografii będzie polegał na wprowadzeniu danych z publikacji związanych z działalnością Wydziału Teologicznego Uniwersytetu Śląskiego. Przede wszystkim zwrócono uwagę na konieczność zamieszczenia danych zaczerpniętych z czasopism, ksiąg jubileuszowych oraz wybranych tomów serii, które ukazały się jako prace zbiorowe. Dotychczas opracowano całą zawartość „Śląskich Studiów Historyczno-Teologicznych” (od 1968 r.) oraz „Studiów Pastoralnych: Rocznika Wydziału Teologicznego Uniwersytetu Śląskiego w Katowicach" (od 2005 r.). Dodatkowo czytelnik ma możliwość dotarcia do wszystkich materiałów opublikowanych w 15 tomach Studiów i Materiałów Wydziału Teologicznego Uniwersytetu Ślaskiego w Katowicach oraz 6 księgach jubileuszowych. Poniższa tabela odzwierciedla liczbowy udział wydawnictw Wydziału Teologicznego w bazie (zob. Tabela 1)

\footnotetext{
${ }^{20}$ Ks. dr Jerzy Witczak (1954-) jest dyrektorem Biblioteki Papieskiego Wydziału Teologicznego i Metropolitalnego Wyższego Seminarium Duchownego we Wrocławiu, a także pełni funkcję Przewodniczącego Federacji Bibliotek Kościelnych FIDES.

${ }^{21}$ J. Witczak, Funkcjonowanie centralnego serwisu, s. 173-177.
} 
Tabela 1. Liczba opracowanych rekordów w EBNT $\mathrm{z}$ podziałem na różne rodzaje dokumentów.

\begin{tabular}{|l|c|}
\hline Publikacje Wydziału Teologicznego Uniwersytetu Śląskiego & Liczba rekordów \\
\hline „Śląskie Studia Historyczno-Teologiczne” & 1.498 \\
\hline „Studia Pastoralne” & 225 \\
\hline $\begin{array}{l}\text { Studia i Materiały Wydziatu Teologicznego Uniwersytetu Śląskiego } \\
\text { w Katowicach }\end{array}$ & 238 \\
\hline Księgi pamiątkowe & 193 \\
\hline Suma opracowanych rekordów & $\mathbf{2 . 1 5 4}$ \\
\hline
\end{tabular}

Źródło: opracowanie własne.

Do końca 2016 r. zostały także opracowane teksty pochodzące z ksiąg pamiątkowych poświęconych ważnym postaciom nauki i Kościoła m.in. ks. prof. Remigiuszowi Sobańskiemu ${ }^{22}$, abp. Damianowi Zimoniowi ${ }^{23}$, prof. Lotharowi Roosowi $^{24}$ oraz ks. prof. Wincentemu Myszorowi ${ }^{25}$. Są to niezwykle ważne pozycje ze względu na swoją unikalną i bogatą zawartość treściową.

W planach pozostaje jeszcze wprowadzenie kolejnych serii:

- Studia Teologiczne i Humanistyczne;

- Kościót w Trzecim Tysiacleciu;

- Źródła do dziejów Kościoła katolickiego na Górnym Śląsu.

${ }^{22}$ Zob. Valeat aequitas: księga pamiatkowa ofiarowana Księdzu Profesorowi Remigiuszowi Sobańskiemu, red. M. Pazdan, Katowice 2000; Sędzia i pasterz: księga pamiatkowa w 50-lecie pracy ks. Remigiusza Sobańskiego w Sadzie Metropolitalnym w Katowicach (1957-2007), red. H. Typańska, Katowice 2007.

${ }^{23}$ Zob. Vobis episcopus vobiscum christianus: księga jubileuszowa dedykowana Księdzu Arcybiskupowi Damianowi Zimoniowi $w$ dwudziestolecie postugi biskupiej w archidiecezji katowickiej oraz w siedemdziesiata rocznice urodzin, red. W. Myszor, A. Malina, Katowice 2004; Praedicamus Christum Crucifixum: Słowo Boże w liturgii Kościoła: Księga Jubileuszowa dedykowana Księdzu Arcybiskupowi Damianowi Zimoniowi Metropolicie Katowickiemu w 25. rocznicę święceń biskupich, red. A. Żądło, Katowice 2010.

${ }^{24}$ Zob. Europa christlich Gestalten: Hoffnung und Angst der Menschen in Europa als Herausforderung für die Soziallehre der Kirche: Festschrift für Prof. Dr. Lothar Roos zum Abschluss seines Wirkens an der Schlesischen Universität, Hrsg. H. Krzysteczko, Katowice 2005.

${ }^{25}$ Zob. Omnia tempus habent: miscellanea theologica Vincentio Myszor quadragesimum annum laboris scientifici celebranti ab amicis, sodalibus discipulisque oblata, red. A. Reginek, G. Strzelczyk, A. Żądło, Katowice 2009. 
Zaangażowanie Biblioteki Teologicznej w prace nad EBNT jest widoczne nie tylko podczas przygotowywania nowych rekordów, ale także na etapie użytkowania bazy. Przede wszystkim informacje o na temat zawartości bibliografii są wyeksponowane na stronie domowej biblioteki (zob. Rysunek 1).

Rys. 1. Informacja o EBNT na stronie Biblioteki Teologicznej.

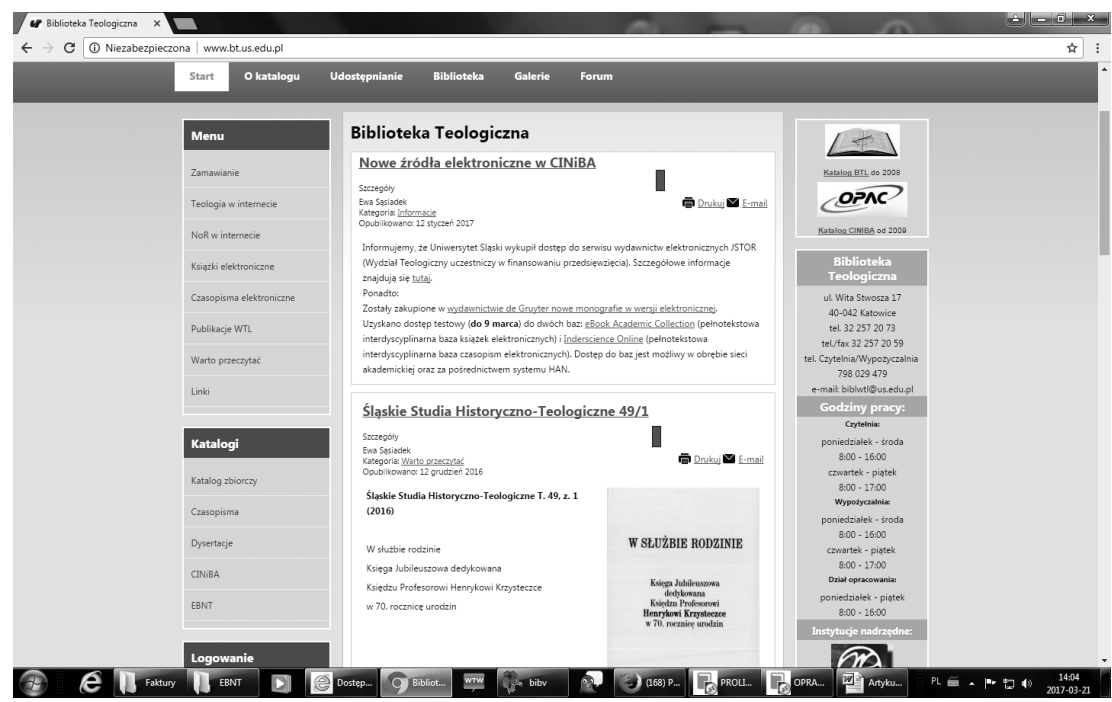

Źródło: http://www.bt.us.edu.pl/ (dostęp: 01.03.2017).

Dodatkowo bibliotekarze szczegółowo omawiają możliwości wyszukiwawcze bazy podczas szkoleń indywidualnych oraz zbiorowych, prowadzonych $\mathrm{w}$ ramach przysposobienia bibliotecznego oraz prowadzonych dla grup seminaryjnych przygotowujących prace dyplomowe ${ }^{26}$. Efektem tego rodzaju działań jest znaczący wzrost wykorzystania nie tylko samej bibliografii, ale także dokumentów zgromadzonych w Bibliotece Teologicznej. A co najważniejsze sami czytelnicy podkreślają, że dzięki $E B N T$ udaje im się dotrzeć do poszukiwanej literatury naukowej, co ułatwia im przygotowanie dysertacji.

\section{Wyszukiwanie i prezentacja informacji}

Początkowo EBNT była udostępniana w postaci samodzielnej bazy w programie MAK WWW na serwerze oraz na platformie multiwyszukiwarki dla komputerowych baz bibliotecznych FIDKAR. Przeszukiwań w bazie można było dokonywać według trzech sposobów: wybór jednego z dostępnych indeksów, połączenie kwerendy w kilku indeksach z wykorzystaniem operatorów Boole'a (,i” oraz „lub”), jak również przez jeden z indeksów i wprowadzenie dodatko-

${ }^{26}$ E. Lubojańska, E. Olszowy, Szkolenia użytkowników w Bibliotece Teologicznej Uniwersytetu Śląskiego w Katowicach, „Fides: Biuletyn Bibliotek Kościelnych”, 2 (39) (2014) s. 90-93. 
wego terminu określonego przez użytkownika. Były to takie indeksy jak: Autor, Tytuł, Słowo w tytule, Hasło przedmiotowe, Indeks rzeczowy oraz Wszystkie indeksy. Dodatkowo przez cały czas zawartość bibliografii można sprawdzać razem z innymi bazami Federacji FIDES za pośrednictwem multiwyszukiwarki FID$\mathrm{KAR}^{27}$. Ogromną zaletą takiego sposobu poszukiwania literatury jest możliwość jednoczesnego przeglądania wielu baz bibliograficznych oraz katalogowych, które zawierają dokumenty $w$ różnych formatach (MARC21, MARCBN, formaty specjalne dla BZCZ, prac dyplomowych, multumediów itp.) oraz pochodzą z bardzo różnorodnych źródeł28. Warto zauważyć, że dodanie $E B N T$ do multiwyszukiwarki FIDKAR w 2011 r. znacząco zwiększyło liczbę dokonywanych wyszukiwań (wzrost nastapił o 25\%) ${ }^{29}$.

Od 2014 r. dzięki pomocy uzyskanej ze strony Janusza Kaczmarka OP ${ }^{30}$ baza działa w systemie Koha, co pozwoliło nie tylko na usprawnienie prac związanych z prowadzeniem i uzupełnianiem bibliografii, ale także znacznie ułatwiło proces wyszukiwania informacji. Co istotne system Koha nie wymaga nakładów finansowych, ponieważ jest oparty na idei wolnego oprogramowania, a cała jego obsługa odbywa się z poziomu przeglądarki internetowej. Dodatkowo, jako systemem zintegrowany, umożliwia współpracę wielu bibliotek w oparciu o centralne rozwiązania informatyczne, w pełni respektuje format MARC 21, wspiera kartoteki haseł wzorcowych oraz umożliwia korzystanie z protokołu Z39.50 (zarówno w trybie klienta, jak i jako serwer). Poza tym nie bez znaczenia pozostaje fakt, że jako system otwarty zapewnia pełną kontrolę nad gromadzonymi danymi, umożliwiając ich eksport $\mathrm{w}$ dowolnej chwili i w dowolnej formie ${ }^{31}$. Dzięki zmianie oprogramowania EBNT ma szansę na stały rozwój, zaistniała bowiem możliwość

${ }^{27}$ Multiwyszukiwarka FIDKAR pozwala na prowadzenie wyszukiwań katalogowych i bibliograficznych w katalogach polskich bibliotek kościelnych, zagranicznych bibliotek narodowych, w wybranych katalogach starych druków i prac dyplomowych z uczelni teologicznych, bibliografiach Federacji FIDE oraz NUKAT. FIDKAR uruchomiono na stronie domowej Federacji FIDES w 2004 roku i obecnie udostępnia ponad 100 bazach danych: K. Gonet, FIDKAR - a co to jest?, „Fides: Biuletyn Bibliotek Kościelnych”, 1/2(18/19) (2004), s. 5; zob. także K. Gonet, M. Marks, Czy FIDKAR jest konkurencja dla KaRo?: protokót Z.39.50 oraz aplikacje FIDKAR i FIDSERW, w: Automatyzacja bibliotek publicznych, red. E. Górska, Warszawa 2005, s. 111-124; K. Gonet, FIDKAR a dalsze losy Katalogu Centralnego FIDES - zachęta do dyskusji, „Fides: Biuletyn Bibliotek Kościelnych”, 1/2 (2004) s. 18-21.

${ }^{28}$ J. Woźniak, FIDKAR, czyli (bardzo krótka) pochwała rozsądku, umiaru i kompetencji, „Fides: Biuletyn Bibliotek Kościelnych”, 1/2(18/19) (2004) s. 12.

${ }^{29}$ Witczak, Funkcjonowanie centralnego serwisu, s. 179.

${ }^{30}$ O. Janusz Kaczmarek OP (1969-), dominikanin, był dyrektorem Biblioteki Kolegium Filozoficzno-Teologicznego Dominikanów w Krakowie, inicjator zastosowania systemu bibliotecznego Koha najpierw w bibliotekach dominikańskich, a potem również w bibliotekach Federacji FIDES, obecnie administrator centralnego katalogu FIDES oraz EBNT w systemie Koha: T. Garwoliński, Biogramy nowych członków honorowych Federacji Bibliotek Kościelnych FIDES, „Fides: Biuletyn Bibliotek Kościelnych", 1(42) (2016) s. 354.

${ }^{31}$ J. Kaczmarek, Wdrożenie zintegrowanego systemu informatycznego dla bibliotek Koha w Bibliotece Kolegium Filozoficzno-Teologicznego oo. Dominikanów w Krakowie, „Fides: Biuletyn Bibliotek Kościelnych”, 1/2(32/33) (2011) s. 27. 
zdalnego wprowadzania i edytowania opisów bibliograficznych z wykorzystaniem różnych kartotek wzorcowych przez wiele bibliotek równocześnie.

Obecnie w opracowaniu przedmiotowym wykorzystywany jest język haseł przedmiotowych Biblioteki Narodowej, natomiast hasła autorskie zgodne są z kartoteką wzorcową NUKAT. Rekordy bibliograficzne tworzone są w formacie MARC21 i - oprócz podstawowych danych charakterystycznych dla opisu bibliograficznego dla artykułu z czasopisma - uzupełniane są o śródtytuły (w polu 520), tytuły obcojęzyczne (w polu 246) oraz linki do pełnych tekstów w bibliotekach cyfrowych (w polu 856) (zob. Rysunek 2).

Rys. 2. Struktura rekordu w module do wprowadzania danych

003 FIDES

$005 \quad 20161115141946.0$

$008 \quad 161115 \mathrm{~s} 2007 \mathrm{pl}|||||||||| 0$ pol c

$040 \quad$ \#\# \$a KAT U/29 AM \$c KAT U/29 AM

1001 1\# \$a Klupczyński, Antoni \$d (1962- ). \$0 n 2006102289 \$9 8613

24513 \$a Pytanie o istnienie i funkcję "prywatnych" wypowiedzi papieskich : \$b czy istnieją "prywatne" wypowiedzi papieskie? / \$c Antoni Klupczyński.

24613 \$a La questione dell'esistenza e della funzione delle enunciazioni "private" dei papi

520 8\# \$a I. "Prywatne" jako oddzielone? II. Jezus we wspólnocie z Ojcem - Syn Boży. III. Magisterium Kościoła i "prywatność" wypowiedzi papieskich. IV. Posługa w tajemnicy Boga. V. Wnioski.

$655 \quad$ \#4 \$a Mowy i homilie papieskie \$0 p 2004319041 \$9 18249

773 0\# \$i W: \$t Charyzmat osoby i autorytet urzędu : wokół pytania o "gatunki literackie" współczesnych wypowiedzi papieskich oraz Stolicy Apostolskiej / red. Grzegorz Strzelczyk. - \$d Katowice : Księgarnia św. Jacka : Wydział Teologiczny Uniwersytetu Śląskiego, 2007. - \$k (Studia i Materiały Wydziału Teologicznego Uniwersytetu Śląskiego w Katowicach ; nr 38). - \$g S. 64-74

999 \#\# \$c 101218 \$d 101218

Ten sam rekord w wersji dostępnej dla użytkownika prezentuje Rysunek 3.

Rys. 3. Rekord w module dla użytkowników

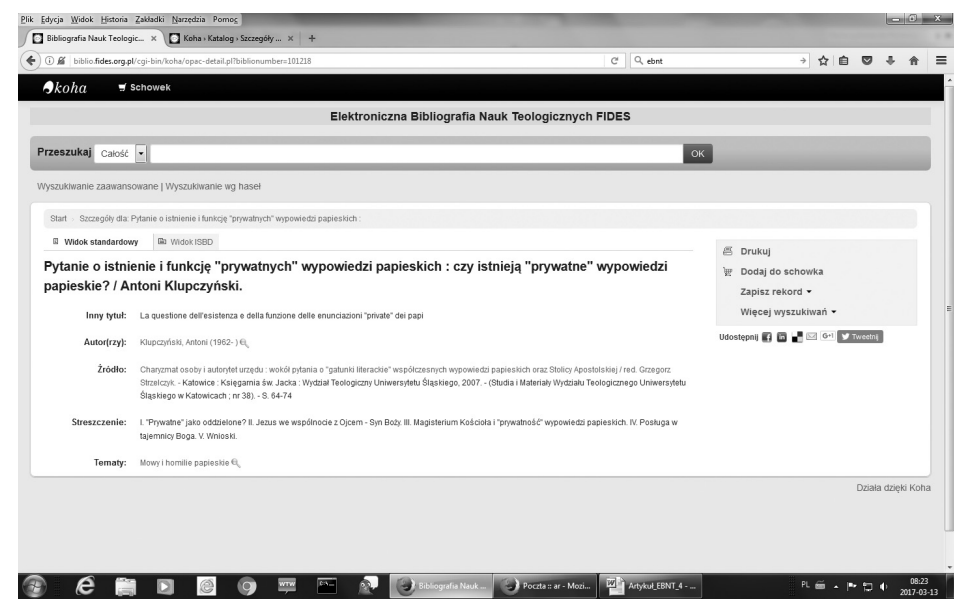

Źródło: http://biblio.fides.org.pl/cgi-bin/koha/opac-main.pl (dostęp: 01.03.2017). 
Przejście na system KOHA wpłynęło także na usprawnienie procesu wyszukiwania informacji w bazie. Obecnie instrukcję wyszukiwawczą można wprowadzić albo w pojedynczym polu na stronie głównej $E B N T$, albo z wykorzystaniem rozbudowanych formularzy przeznaczonych do wyszukiwania zaawansowanego oraz według hasel. Najprostszym sposobem dotarcia do potrzebnych danych bibliograficznych jest wpisanie słowa lub frazy z jednoczesną możliwością wyboru jednego z czterech indeksów: Całość (czyli w obrębie całego opisu), Tytuł, Autor oraz Temat. Natomiast wyszukiwanie zaawansowane pozwala użytkownikowi na sterowanie procesem selekcjonowania informacji poprzez:

- zastosowanie operatorów Boole'a;

- wyznaczenie przedziału czasowego;

- wskazanie miejsca występowania poszukiwanych terminów w dokumencie (np. tytuł, temat);

- sortowanie uzyskanych wyników według daty wydania, popularności, tytułów oraz autorów (w kolejności alfabetycznej);

- wyszukiwanie w wynikach bieżącej listy trafień.

Ponadto istnieje możliwość rozbudowanego wyszukiwania przez wszystkie typy haseł wzorcowych oraz słowa kluczowe. Z punktu widzenia użytkownika baza daje wiele możliwości dotarcia do potrzebnych informacji i jednocześnie pozwala na dostosowanie uzyskanych wyników do własnych potrzeb.

\section{Zakres, zasięg i odbiorcy bibliografii}

Od początku przyjęto zasadę, że baza ma indeksować w całości zawartość polskich czasopism teologicznych, religioznawczych i z szeroko rozumianych nauk kościelnych, w tym filozofii chrześcijańskiej i prawa kanonicznego, jak też prace z wybranych publikacji zbiorowych (serii wydawniczych, ksiąg jubileuszowych, materiałów konferencyjnych itp.). Dodatkowo ewidencjonuje niewielką liczbę opisów artykułów wybranych z innych czasopism i prac zbiorowych. Zawiera pozycje wydawane w Polsce, przede wszystkim przez uczelnie kościelne, wydziały teologiczne oraz diecezjalne i zakonne instytucje naukowe, jakkolwiek nie wszystkie teksty można zaliczyć do zakresu nauk teologicznych. Zasięg chronologiczny bazy obejmuje zasadniczo piśmiennictwo od roku 1980, choć niektóre tytuły są opracowane w całości i dlatego czasem można napotkać także teksty pochodzące z lat wcześniejszych. W zamierzeniu redaktorów EBNT ma stanowić kontynuację wspomnianej wcześniej Polskiej Bibliografii Nauk Kościelnych za Rok..., która rejestrowała publikacje wydane do $1979 \mathrm{r}$.

Pomimo, że najważniejszą oraz najobszerniejszą część bibliografii stanowią czasopisma teologiczne, to jednak można tu również napotkać wiele pozycji o charakterze ogólnohumanistycznym i społecznym. Analiza zawartości tematycznej pozwala wyodrębnić wiele artykułów z zakresu historii, filozofii, socjologii, pedagogiki, psychologii, nauk o rodzinie czy kulturoznawstwa. Z kolei analiza ilościowa zarejestrowanych periodyków, pokazuje wzrost liczby tytułów czasopism o ponad 40 pozycji w ciągu ostatnich pięciu lat, co pozwala wnioskować, że ma to związek z przyrostem publikacji i podejmowanych badań, a tym samym także rozwojem nauk teologicznych. Tego rodzaju tendencję potwierdza także 
wciąż powiększająca się liczba serii wydawanych przez polskie ośrodki kościelne i świeckie. Ich obecność w bazie ma duże znaczenie, ponieważ najczęściej zawierają materiały konferencyjne stanowiące odzwierciedlenie działalności naukowej. Najwięcej tego rodzaju publikacji pochodzi z wydziałów teologicznych działających na państwowych uniwersytetach oraz z uczelni kościelnych. W Uniwersytecie Opolskim opracowane są wszystkie serie wydawane przez Wydział Teologiczny (Colloquia Theologica; Człowiek, Rodzina, Spoleczeństwo; Ekumenizm i Integracja; Musica Claromontana; Opolska Biblioteka Teologiczna; Sympozja; Z Dziejów Kultury Chrześcijańskiej na Śląsku), co świadczy nie tylko o aktywności naukowej samego wydziału, ale także o zaangażowaniu pracowników biblioteki w przygotowanie rekordów. Wiele zarejestrowanych serii pochodzi również z Papieskiego Wydziału Teologicznego (Colloquia Wratislaviensia; De Fratrum Nostrorum Consilio; Konferencje i Sesje Naukowe; Rozprawy Naukowe; Sympozja i Sesje Naukowe; Opera Theologiae Systematicae). W EBNT widoczne są także informacje o tytułach wydawanych przez uczelnie kościelne, np. Katolicki Uniwersytet Lubelski Jana Pawła II (Analecta Biblica Lublinensia; Biblioteka Teologii Religii; Homo Meditans; Religia i Mistyka; Teologia w Dialogu) oraz Uniwersytet Kardynała Stefana Wyszyńskiego w Warszawie (Ad Multos Annos; Mistyka Chrześcijańska; Mistyka Polska). Jednak ich liczba wydaje się być niewystarczająca w stosunku do oferty wydawniczej tych instytucji. Należy podkreślić, że ewidencjonowanie tego rodzaju piśmiennictwa to doskonały sposób na promocję nie tylko publikacji i ich autorów, ale także ośrodków naukowych, w których powstają ${ }^{32}$.

Innym ważnym elementem bazy są opisy bibliograficzne pochodzące z ksiąg jubileuszowych, ponieważ najczęściej - jako prace zbiorowe - zawierają materiały, które nie są nigdzie rejestrowane i w związku z tym najtrudniej je odnaleźć. Najczęściej do tworzenia ksiąg zapraszani są wybitni naukowcy nie tylko z Polski, ale także z zagranicy, co powiększa wartość oraz zróżnicowanie prezentowanych treści. EBNT odnotowuje blisko 50 tego rodzaju tytułów, wydawanych od 1974 r. i najczęściej poświęconych wybitnym ludziom nauki i Kościoła, np. kard. Józefowi Glempowi ${ }^{33}$, kard. Bolesławowi Kominkowi ${ }^{34}$.

Różnorodność prezentowanych dokumentów oraz stosunkowo szeroki zakres tematyczny bazy, często wykraczający poza obszar dyscyplin teologicznych sprawia, że $E B N T$ może być wykorzystywana przez duży krąg odbiorców. Adresatami spisu mogą być nie tylko osoby związane z akademicką teologią (studenci lub na-

${ }^{32}$ D. Buzdygan, Bibliograficzna baza danych - promocją czasopism, artykułów, autorów i instytucji, w: Bibliograficzne bazy danych i ich rola w rozwoju nauki. II Konferencja naukowa Konsorcjum BazTech, Poznań, 17-19 kwietnia 2013, http://open.ebib.pl/ojs/index.php/Mat_konf/article/ view/22 (dostęp: 01.03.2017).

${ }^{33}$ Zob. Trwać pod spojrzeniem Pana: księga pamiątkowa Uniwersytetu Kardynała Stefana Wyszyńskiego w Warszawie dla Jego Eminencji Księdza Kardynała Józefa Glempa, Prymasa Polski, Arcybiskupa Warszawskiego, Wielkiego Kanclerza UKSW w dwudziesta piąta rocznicę święceń biskupich, red. A.F. Dziuba, Warszawa 2004.

${ }^{34}$ Zob. Verbum crucis: kardynałowi Bolesławowi Kominkowi w hołdzie, red. J. Krucina, współaut. M. Rechowicz [et al.], Wrocław 1974. 
ukowcy), ale także czytelnicy chcący zgłębiać zagadnienia wiary i nauki Kościoła katolickiego, ponieważ są tu również obecne pozycje o charakterze popularnonaukowym. Znaczna część rekordów bibliograficznych zawiera opisy pochodzące z dokumentów, które można zaklasyfikować do wielu dziedzin humanistycznych jednocześnie, dlatego mogą ją przeglądać historycy, filozofowie, filologowie, socjologowie, kulturoznawcy, pedagodzy, specjaliści nauk o rodzinie itp. Dodatkowo powinni ją znać specjaliści z informacji naukowej oraz bibliotekarze, którzy na co dzień służą pomocą w tworzeniu kwerend oraz poszukiwaniach literaturowych. Inną grupę użytkowników mogą stanowić pracownicy katolickich oficyn drukarskich i wydawniczych, redakcji czasopism wyznaniowych (i innych), archiwów i muzeów kościelnych oraz członkowie zakonów i zgromadzeń zakonnych $^{35}$.

\section{Podsumowanie}

Bibliograficzne bazy danych, a szczególnie dziedzinowe takie jak $E B N T$, coraz bardziej zyskują na popularności w środowisku akademickim i stanowią niezwykle ważny element dla prowadzenia badań i rozwoju nauki ${ }^{36}$. Jak słusznie zauważa Małgorzata Kowalska: „Rejestracja specjalistycznych czasopism czy niskonakładowych materiałów konferencyjnych czyni je kompleksowym i aktualnym źródłem informacji na temat tendencji rozwojowych w poszczególnych dziedzinach i dyscyplinach naukowych" ${ }^{37}$. Pomimo, że często uznawane są za składową tzw. ukrytego Internetu, to jednak dzięki zastosowaniu odpowiednio zorganizowanego procesu wyszukiwania dają bardziej wiarygodne i aktualne wyniki aniżeli te, które można znaleźć, przeszukując Internet przy pomocy ogólnych wyszukiwarek $^{38}$. Analiza zawartości $E B N T$ pokazała, że baza spełnia wszystkie wymogi stawiane współczesnym bibliografiom dziedzinowym. W profesjonalny sposób rejestruje i prezentuje zawartość aktualnego czasopiśmiennictwa oraz wybranych prac zbiorowych. Jednocześnie często odnotowuje opisy pochodzące $\mathrm{z}$ archiwalnych numerów niektórych tytułów co sprawia, że należy ją traktować nie tylko jako bibliografię bieżącą, ale i retrospektywną, choć niekompletną. Wymaga bowiem jeszcze pewnych uzupełnień, szczególnie w zakresie ewidencjonowania wydawnictw seryjnych i zbiorowych. Ponadto, aby mogła stanowić kontynuację Polskiej Bibliografii Nauk Kościelnych za Rok... wydawanej przez Akademię Teologii Katolickiej, jak to zakładali jej twórcy w momencie uruchamiania,

${ }^{35}$ R. Żmuda, Kościelne dyscypliny naukowe bez bibliografii?, „Saeculum Christianum”, 2 (2011) s. $302-303$.

${ }^{36}$ Sadowska, Polskie dziedzinowe bibliograficzne.

${ }^{37}$ M. Kowalska, Zasoby czasopiśmiennicze w polskich bibliotekach cyfrowych i bibliograficznych bazach danych - koegzystencja, konkurencja czy kooperacja?, w: Bibliograficzne bazy danych: kierunki rozwoju i możliwości wspótpracy. Ogólnopolska konferencja naukowa z okazji 10-lecia bazy danych BazTech. Bydgoszcz, 27-29 maja 2009, [Warszawa] 2009 http://www.ebib.pl/ publikacje/matkonf/mat19/kowalska.php (dostęp: 01.03.2017).

${ }^{38} \mathrm{~B}$. Jaskowska, Ukryty Internet - jakie korzyści mogą mieć z niego naukowcy i praktycy?, „Zarządzanie Zasobami Ludzkimi”, 1 (2007) s. 79-87. https://www.ipiss.com.pl/wp-content/uploads/ downloads/2012/11/b_jaskowska_zzl_1_2007.pdf (dostęp: 01.03.2017). 
należy oczekiwać większego zaangażowania bibliotek członkowskich Federacji Bibliotek Kościelnych FIDES w prace bibliograficzne.

\section{BIBLIOGRAFIA}

Bajor Agnieszka, Langer Hanna, Polskie spisy i serwisy bibliograficzne dostepne w Internecie, w: Biblioteki szkół wyższych w społeczeństwie wiedzy: uwarunkowania $i$ wybrane zagadnienia, t. 1, Konteksty $i$ uwarunkowania, red. Z. Gębołyś, Katowice 2010, s. 106-149.

Buzdygan Dorota, Bibliograficzna baza danych - promocja czasopism, artykułów, autorów $i$ instytucji, w: Bibliograficzne bazy danych i ich rola $w$ rozwoju nauki. II Konferencja naukowa Konsorcjum BazTech, Poznań, 17-19 kwietnia 2013, http://open.ebib. pl/ojs/index.php/Mat_konf/article/view/22 (dostęp: 01.03.2017).

Dziewiątkowski Janusz Adam, Automatyzacja procesów biblioteczno-informacyjnych w świetle działalności Federacji Bibliotek Kościelnych „Fides”, „Fides: Biuletyn Bibliotek Kościelnych", 1 (1998) s. 7-71.

Garwoliński Tomasz, Biogramy nowych członków honorowych Federacji Bibliotek Kościelnych FIDES, „Fides: Biuletyn Bibliotek Kościelnych”, 1(42) (2016) s. 354-356.

Gonet Krzysztof, Autobiografia bibliotekarza i bibliotekoznawcy. (Do października roku 2016), „Fides: Biuletyn Bibliotek Kościelnych”, 1(44) (2017) s. s. 181-190.

Gonet Krzysztof, Witczak Jerzy, Apel Federacji Bibliotek Kościelnych FIDES do uczestników Kongresu Teologów Polskich Lublin, 12-15 września 2004 r., „Fides: Biuletyn Bibliotek Kościelnych”, 1-2(20-21) (2005) s. 189-190.

Gonet Krzysztof, FIDKAR - a co to jest?, „Fides: Biuletyn Bibliotek Kościelnych”, $1 / 2(18 / 19)(2004)$ s. 5-10.

Jaskowska Bożena, Ukryty Internet - jakie korzyści moga mieć z niego naukowcy i praktycy?, „Zarządzanie Zasobami Ludzkimi”, 1 (2007) s. 79-87, https://www.ipiss.com.pl/wp-content/uploads/downloads/2012/11/b_jaskowska_zzl_1_2007.pdf (dostęp: 01.03.2017).

Kaczmarek Janusz, Wdrożenie zintegrowanego systemu informatycznego dla bibliotek Koha w Bibliotece Kolegium Filozoficzno-Teologicznego oo. Dominikanów w Krakowie, „Fides: Biuletyn Bibliotek Kościelnych”, 1/2(32/33) (2011) s. 25-30.

Kowalska Małgorzata, Zasoby czasopiśmiennicze w polskich bibliotekach cyfrowych $i$ bibliograficznych bazach danych - koegzystencja, konkurencja czy kooperacja?, w: Bibliograficzne bazy danych: kierunki rozwoju i możliwości wspótpracy. Ogólnopolska konferencja naukowa z okazji 10-lecia bazy danych BazTech. Bydgoszcz, 27-29 maja 2009, [Warszawa] 2009, http://www.ebib.pl/publikacje/matkonf/mat19/kowalska.php (dostęp: 01.03.2017).

Lubojańska Eliza, Olszowy Ewa, Szkolenia użytkowników w Bibliotece Teologicznej Uniwersytetu Śląskiego w Katowicach, „Fides: Biuletyn Bibliotek Kościelnych”, 2 (39) (2014) s. 89-102.

Sadowska Jadwiga, Główne problemy współczesnej polskiej bibliografii, w: Bibliografia: teoria, praktyka, dydaktyka: praca zbiorowa, red. J. Woźniak-Kasperek, M. Ochmański, Warszawa 2009, s. 34-46.

Sadowska Jadwiga, Polskie dziedzinowe bibliograficzne bazy danych $w$ perspektywie lokalnej i globalnej, w: Bibliograficzne bazy danych: kierunki rozwoju i możliwości wspótpracy. Ogólnopolska konferencja naukowa z okazji 10-lecia bazy danych Baz- 
Tech. Bydgoszcz, 27-29 maja 2009, [Warszawa] 2009, http://www.ebib.pl/publikacje/ matkonf/mat19/sadowska.php (dostęp: 01.03.2017).

Szumilas Dorota, Warzeszak Stanislaw, Baza danych bibliograficznych z zakresu teologii moralnej $i$ etyki (http://www.biblioteka.uksw.edu.pl/), „Warszawskie Studia Teologiczne", XXII/1 (2009) s. 358-362.

Szumilas Dorota, Dziedzinowe bazy bibliograficzne Biblioteki Uniwersytetu Kardynała Stefana Wyszyńskiego w Warszawie, w: Bibliograficzne bazy danych: kierunki rozwoju i możliwości współpracy. Ogólnopolska konferencja naukowa z okazji 10-lecia bazy danych BazTech. Bydgoszcz, 27-29 maja 2009, red. L. Derfert-Wolf, L. Szczepańska, [Warszawa] 2009, http://www.ebib.pl/publikacje/matkonf/mat19/szumilas. php (dostęp: 01.03.2017).

Witczak Jerzy, 25 lat komputeryzacji bibliotek kościelnych $w$ Polsce - dorobek Federacji FIDES, „Archiwa Biblioteki i Muzea Kościelne”, 106 (2016) s. 333-342.

Witczak Jerzy, Apel FIDES do polskich teologów i co dalej?, „Fides: Biuletyn Bibliotek Kościelnych", 1-2(20-21) (2005) s. 193-195.

Witczak Jerzy, Elektroniczna Bibliografia Nauk Teologicznych Federacji FIDES, Wrocław 3.09.2013 [prezentacja].

Witczak Jerzy, Funkcjonowanie centralnego serwisu informacji katalogowej i bibliograficznej FIDES w 2011 roku, „Fides: Biuletyn Bibliotek Kościelnych”, 1(34) (2012) s. $177-178$.

Woźniak Jadwiga, FIDKAR, czyli (bardzo krótka) pochwała rozsądku, umiaru i kompetencji, „Fides: Biuletyn Bibliotek Kościelnych”, 1/2(18/19) (2004) s. 12.

Żmuda Ryszard, Kościelne dyscypliny naukowe bez bibliografii?, „Saeculum Christianum", 2 (2011) s. 283-304.

\section{ELEKTRONICZNA BIBLIOGRAFIA NAUK TEOLOGICZNYCH JAKO ŹRÓDLO DO BADAŃ HISTORYCZNO-TEOLOGICZNYCH}

\section{Streszczenie}

Elektroniczna Baza Nauk Teologicznych powstała w 2011 r. i jest tworzona przez Federację Bibliotek Kościelnych FIDES we współpracy z Biblioteką Narodową. W bibliografii indeksowana jest zawartość polskich czasopism teologicznych, religioznawczych i z szerzej rozumianych nauk kościelnych, zarówno naukowych jak i popularnonaukowych. Ponadto zamieszczane są wybrane prace zbiorowe, serie wydawnicze, księgi jubileuszowe, materiały konferencyjne itp. Pomimo, że najważniejszą oraz najobszerniejszą część bibliografii stanowią czasopisma teologiczne, to jednak można tu również odnaleźć wiele pozycji o charakterze ogólnohumanistycznym i społecznym. Obejmuje głównie publikacje wydawane przez uczelnie kościelne i wydziały teologiczne oraz diecezjalne i zakonne instytucje naukowe.

Zasięg chronologiczny bazy obejmuje zasadniczo piśmiennictwo od roku 1980, choć niektóre tytuły są opracowane w całości i dlatego czasem można napotkać także teksty pochodzące z lat wcześniejszych. Obecnie baza działa w systemie Koha, co pozwala na 
sprawne prowadzenie prac związanych $\mathrm{z}$ tworzeniem i uzupełnianiem bibliografii oraz znacznie upraszcza proces wyszukiwania informacji.

Słowa kluczowe: Elektroniczna Baza Nauk Teologicznych; Federacja Bibliotek Kościelnych FIDES; bibliografie dziedzinowe; bibliograficzne bazy danych; Biblioteka Teologiczna Uniwersytetu Śląskiego

THE ELECTRONIC BIBLIOGRAPHY OF THEOLOGICAL SCIENCES AS A SOURCE FOR HISTORICAL AND THEOLOGICAL RESEARCH

\begin{abstract}
Summary
The Electronic Database of the Theological Sciences was established by the Federation of the Polish Church Libraries FIDES in cooperation with the National Library in 2011. In the bibliography the following items are indexed: the content of Polish theological and religious journals as well as the magazines discussing, broadly understood, church sciences issues. The bibliography includes both academic articles and the ones intended for the general public. In addition, it contains selected joint works, publishing series, jubilee books, conference material etc. Although theological journals are the core of the bibliography, it is also possible to find a number of works on general humanistic and social issues. The publications included in the bibliography are mainly released by church universities, theological faculties as well as diocesan and monastic research institutions.

The chronology of the database covers literature from 1980 onwards; however, due to the fact that the whole titles are analysed, sometimes the texts from previous years may also be encountered. Currently, the database operates in the Koha system, which allows efficient work on creating and supplementing the bibliography. Furthermore, the system significantly facilitates the information search process.
\end{abstract}

Keywords: the Electronic Bibliography of Theological Sciences; the Federation of the Polish Church Libraries FIDES; specialist bibliographies; bibliographic database; the Theological Library of the University of Silesia 